\title{
Manufacture, use and management of macro-lithic resources in the Bronze Age settlement of Bruszczewo (Poland)
}

\author{
Selina Delgado-Raack ${ }^{1}$, Jutta Kneisel ${ }^{2}$, Janusz Czebreszuk ${ }^{3}$, Johannes Müller ${ }^{2}$ \\ 1. Department of Prehistory, Autonomous University of Barcelona, Facultat de Lletres, Edifici B, E-08193 \\ Bellaterra, Barcelona, Spain. Email: selina.delgado@uab.cat \\ 2. Institute of Pre- and Protohistoric Archaeology, Christian-Albrechts University, Johanna-Mestorf-Straße 2-6, \\ D-24098 Kiel, Germany. Email: Kneisel: jutta.kneisel@ufg.uni-kiel.de; Muller: johannes.mueller@ufg.uni- \\ kiel.de \\ 3. Institute of Archaeology, Adam Mickiewicz University, Poznań, Poland. Email: jancze@main.amu.edu.pl
}

\begin{abstract}
:
Contrary to pottery or metal artefacts, macro-lithic tools are still not fully integrated into the archaeological research programs concerning the Early Bronze Age of Central Europe. While such kind of archaeological materials usually do not easily allow typological approaches, their constant participation in several productive spheres makes them a crucial element for understanding the economic processes and the organisation of past societies. This paper presents the general results of the investigation carried out on an assemblage of 1073 macro-lithic items recovered in the wet soil area of the site of Bruszczewo (municipality of Śmigiel, Poland). This fortified settlement was inhabited during the Early Bronze Age (2100-1650 BCE) and later on in the Late Bronze Age and Early Iron Age (1100-800 BCE), with minor archaeological evidences from Middle Ages. The methodology applied in this assessment is a holistic one, which combines manufacturing (petrography and morphometry), functional (use-wear and residues) and spatial analyses. This approach has allowed recording a mainly local raw material supplying system, based on the gathering of pebbles in the vicinity of the site and a minimal transformation of raw pieces previous to use. Moreover, Bruszczewo comes out to be a central settlement managing and controlling exogenous ores, such as copper and gold, as shown by residues found on some macro-lithic forging anvils. All in all, the recognition in the macro-lithic tool assemblage of different tasks related to subsistence (food preparation) as well as to manufacture (metallurgy, probably bone working) processes contributes to (a) defining the settlement's organisation and the management of resources in the site and (b) improving our understanding of the role played by central settlements in the socio-economic networks, at a time when the first class societies emerged in Central Europe.
\end{abstract}

Keywords: macro-lithic tools; Únětice; palaeoeconomy; manufacture; functional analysis; grinding; metallurgy

Published by the School of History, Classics and Archaeology, University of Edinburgh ISSN: 2055-0472. URL: http://journals.ed.ac.uk/lithicstudies/

Except where otherwise noted, this work is licensed under a CC BY 4.0 licence. 


\section{Introduction}

\subsection{Chrono-spatial context}

Bruszczewo 5 is a prehistoric settlement located at the municipality of Śmigiel, in the Kościan County of the Lowland of Great Poland province (Figures 1 \& 2). The first excavations in this site were directed by Pieczyński from the Archaeological Museum of Poznan during the1960s and took place on the central and highest part of the settlement (Pieczyński 1985: 167-179). Since the end of the 1990s several excavation campaigns have been carried out on the site in the frame of an interdisciplinary German-Polish project led by the Christian-Albrechts University of Kiel and the Adam Mickiewicz University of Poznan (Czebreszuk \& Müller 2004; Czebreszuk \& Müller 2015; Czebreszuk et al. 2015; Müller et al. 2010).

The settlement was built on a sandy elevation, a peninsula formed on a Vistulian terrace by fluvio-glacial sands, at the border of a peat valley, which was formerly a lake, and is today crossed by the river Samica. At regional level, Bruszczewo lies in the Kościan Plain, some 15 $\mathrm{km}$ to the north of the end-morreanic zone of the Leszno stage (North Polish Glaciation). The whole region is covered by a wide draining fluvio-glacial network, characterized by extensive floodplain terraces separated by wide glacial troughs, which were formed during the Vistulian glaciation (Hildebrandt-Radke 2015: 11-37, fig. 1.9). The latter are pathways for fluvioglacial meltwater flowing and transporting glacial sediments from the Poznan stages. As a result of this activity, several 2 to $4 \mathrm{~m}$ thick secondary deposits carrying pebbles and fluvioglacial sands have been observed in the site (Bork 2010: 39ff.; Hildebrandt-Radke 2010: 23).

The oldest archaeological remains found in the site are attested by 17 Neolithic pottery sherds (Szmyt 2015: 43-51) and stone artefacts. Among the pottery fragments Late Band, Funnel Beaker, Globular Amphora and Corded Ware cultures are represented and they were scattered mainly in the southern half of the site (Szmyt 2015: figs. 3.1 and 3.2). The scarcity of remains and the lack of other archaeological structures speaks for an occasional use of the site between the $5^{\text {th }}$ millennium and the $3^{\text {rd }}$ millennium BCE. The first regular and most important occupation phase is related to the Early Bronze Age, attributed to the Únětice culture (2100-1650 cal. BCE; Table 1). In an early phase of the Early Bronze Age the settlement concentrated within a defensive structure mainly on the top of the hill, reaching the water shore of the Samica Lake around 1800 cal. BCE. These layers have provided the majority of the structural remains in the site consisting of a defensive structure, houses, pits and a lake side refuse area. The settlement was abandoned at the end of the Early Bronze Age around $1650 \mathrm{BCE}$ as a consequence of subsequent flooding, among other reasons (Kneisel et al. 2008: 51-58). After this hiatus in the stratigraphic sequence, the site was again inhabited during the Late Bronze Age until the Early Iron Age (1100-500 cal. BCE) but only marginally, as the main settlement was moved to an area located southwestern of Bruszczewo, where also a Lusatian necropolis was set up. The most recent remains known in the site are related to Early Medieval times. 


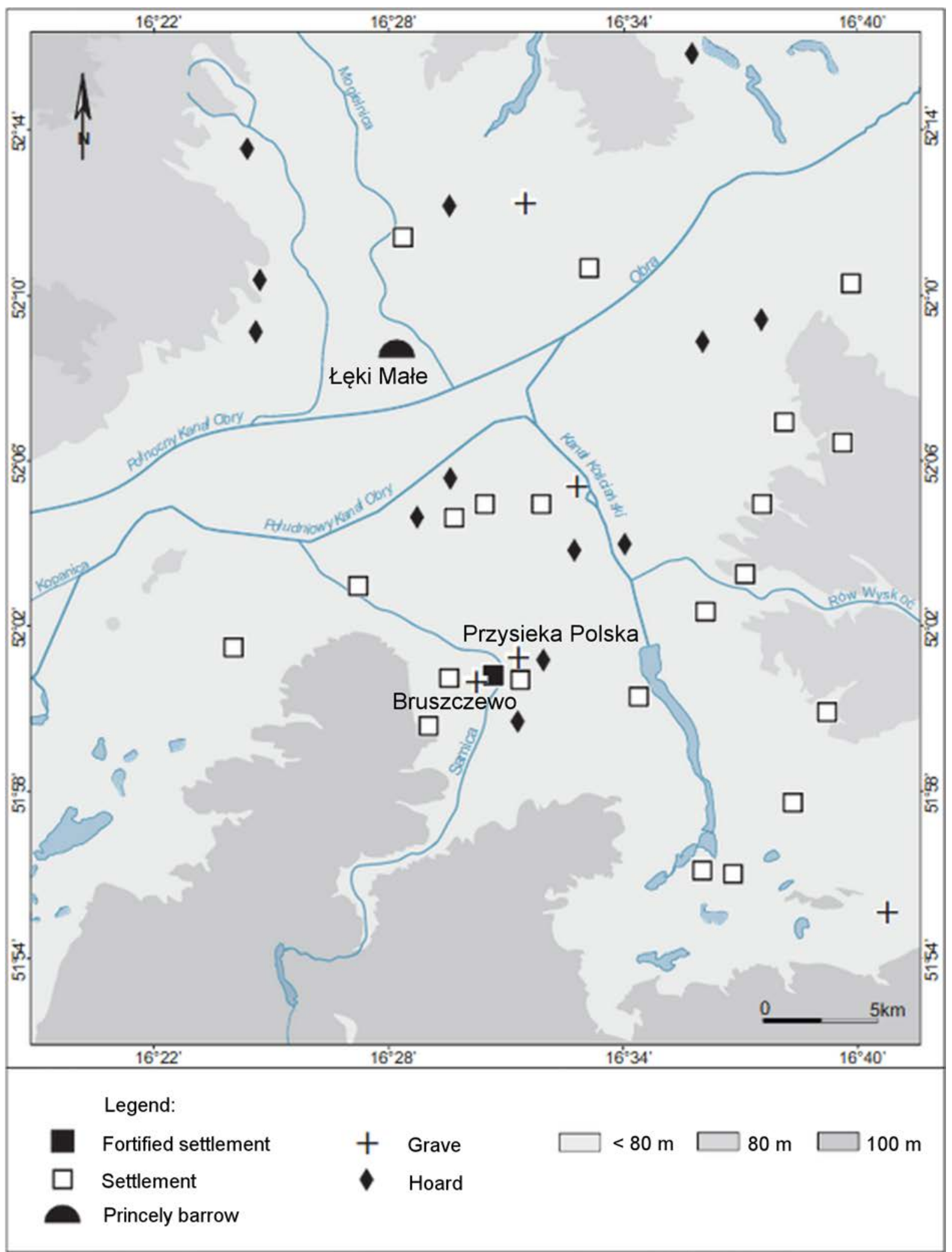

Figure 1. Kościan region with Early Bronze Age archaeological sites (adapted from Müller \& Czebreszuk 2010: Abb. 2). 


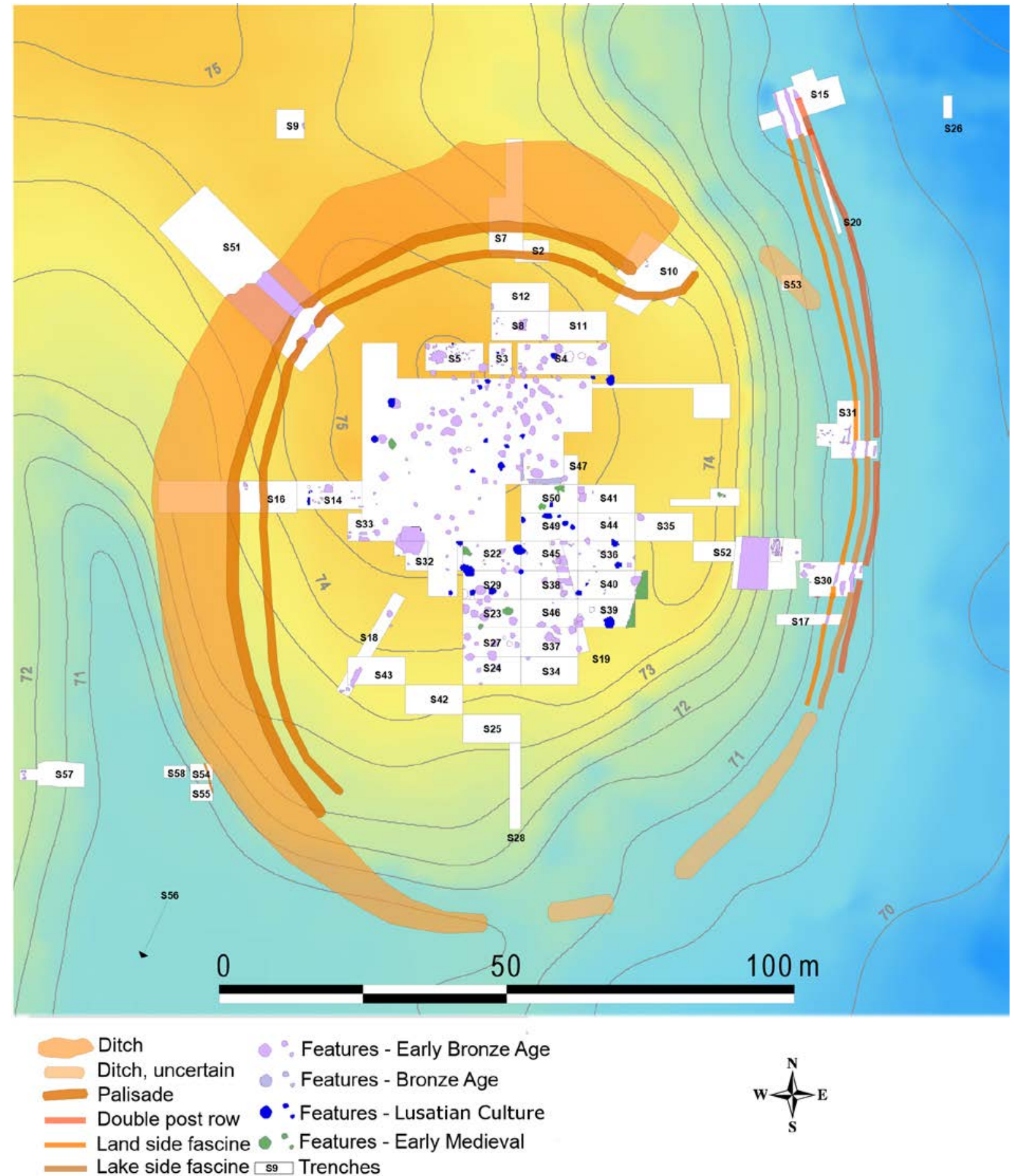

Figure 2. Plan of Bruszczewo, with the excavated trenches. The mineral soil area is represented by warm colours, while the wet soil area coincides with cold colours. 
Table 1. Chronological sequence of Bruszczewo.

\begin{tabular}{lll}
\hline cal. BCE & Period & Culture \\
\hline 1100 & Late Bronze Age and Early Iron Age & $\begin{array}{c}\text { Lusatian culture } \\
\text { Hiatus }\end{array}$ \\
1650 & & Transgression \\
2100 & Early Bronze Age & Únětice culture \\
5 th-3rd & Neolithic & Few findings of pottery: Late Band, \\
millennia & & Funnel Beaker, Globular Amphora, \\
& & Corded Ware \\
\hline
\end{tabular}

The specific features of the Early Bronze Age occupation make Bruszczewo one of the most important sites in the context of the Únětice culture in Central Europe. On the one hand, the site is placed on both a dry and a wetland area, today a peat bog. The transgression episode at the end of the Early Bronze Age provided a unique situation from the point of view of the preservation of the remains, favouring mineral soil preservation as well as water-logged archaeological remains, especially organic materials, conserved in the shallow waters of the lake edge (Kneisel \& Kroll 2010: 576-661). This turns Bruszczewo into the only Únětice site known up to date with wet soil findings. On the other hand, its location at the very eastern end of the distribution area of the Unětice culture, makes it the only fortified settlement for this period in the area (Müller \& Czebreszuk 2010: Abb. 1). Finally, in the Kościan region, as part of the north European plain, there is a clear lack of raw materials as amber, copper or gold. But some final products made of these raw materials have been recovered in the princely graves of Łęki Małe and other Early Bronze Age hoards found in the vicinity of Bruszczewo, as well as on the site itself. Moreover, as there will be pointed out further in this article, in Bruszczewo there is evidence of transformation and manufacturing of metal objects in situ.

\subsection{Previous research}

Taking into account the chrono-spatial context briefly outlined here, this paper presents the main results of a systematic study done on the total amount of macro-lithic items recovered from the most recent excavation campaigns (2004-2009) developed in the wet soil area of the site (mainly trenches S30, S31 and S52, see Figure 2). The aim of this study is to technologically and functionally assess the macro-lithic tools (so called ground stone tools elsewhere) which were manufactured and used during the occupation of the site. A lot of publications have enriched the knowledge about the Bronze Age in the Kościan region since the beginning of the research process of Bruszczewo. In spite of this, only two partial studies exist regarding macro-lithic assemblages, which use their own terminology, independent one from each other:

- Honig (2004: 247-256) presented the artefacts recovered in trench S15 (Figure 2) of the northern part of the wet soil area, a peripheral zone of the settlement, probably belonging to the refuse area of the lake side. In this study a series of percussors, grinding stones, axes and flint artefacts were included.

- Szydłowski (2015: 235-242) studied mainly artefacts from the mineral soil area, defined by him as pestles, pestle-grinders, whetstones, polishing-stones, quernstones, rest-stones, polishers, anvils and axe-hammers.

To contribute to better understand the economic processes of controlling raw materials, their transformation into artefacts and their use as means of production in the context offered by Bruszczewo during the Early Bronze Age, this study also takes into account data coming from both former publications when it comes to the spatial evaluation of the macro-lithic artefacts, although none of them explains explicitly how their artefact types have been defined nor in which publication this information can be checked. 


\section{Materials and methods}

This paper presents a technological and functional study of the macro-lithic assemblage recovered in Bruszczewo, which also focuses on the aspect of the management of stone resources and tools in time and space. The collection includes 1073 macro-lithic items excavated by the German-Polish team in the eastern wet soil area and distributed through the whole stratigraphic sequence of the site. Stone items were collected systematically during the excavation. This is the reason why (a) the macro-lithic assemblage analysed can be considered representative of the preserved archaeological deposit and (b) it can be concluded that a great amount of the items are not artefacts, but raw pieces (see Section 3).

Seeking for a functional interpretation of the macro-lithic tools, the assemblage was recorded according to a standardized system designed for the systematic study of macro-lithic artefacts and on the basis of which several thousands of such items have already been analysed (Delgado-Raack 2008; Risch 2002). Macro-lithic inventories are known to be not necessarily suitable for chrono-typological approaches, as they show few technological attributes changing or evolving during time. Opposite to this, they participate in a large variety of productive sequences within the chaîne opératoires and show different stages in the use life of one and the same artefact type. As it has been demonstrated in the last decades, this kind of tools is much more interesting from the point of view of a paleoeconomic reconstruction aiming to define the raw material supply, manufacturing process acting on the raw pieces, the functions of the tools and the spatial management of them in the social context. These aspects allow retrieving information on stone artefacts in relation to the different technological stages of the Basic Economic System (Risch 2008: 513-521), that is to say, (a) as socially appropriated raw material, (b) as work object, which undergoes intentional anthropic transformation processes and (c) as work means, once integrated in a subsequent productive process with the aim of transforming other raw materials. As a result, from a material perspective, raw materials will exhibit a series of production traces in every production system, among which transformation (work object) as well as use-wear traces (work mean) are included.

\subsection{Raw material supply}

The characterization of the artefacts as raw materials, together with the work objects which are being transformed (see Section 2.2), allows an evaluation of the efforts put in the manufacturing of the tools. This effort can be related to the distance from the natural source or even the type of supplying (i.e., spatially concentrated outcrop versus extensive fluvial deposits). The present work assesses this issue first, through the petrographic determination of the rocks (of the artefacts as well as raw pieces) found in Bruszczewo. The petrographic approach was based on non-destructive macro- and mesoscopic observation of specimens, using habitual petrographic procedures such as granulometric charts, field (20x magnification) and stereoscopic (up to 60x magnification) loupes, guides (Rudolph 2008; 2010) and specialized publications on the geomorphological context of the site and its neighbourhood (Bork 2010: 38-49; Hildebrandt-Radke 2010; 2015: 11-37).

Second, as this analysis also seaks for determining the specific nature of the exploited resources, the raw material recovered in the site of Bruszczewo was evaluated through its morphological features, as manifest in the still preserved natural surfaces of both, raw pieces and artefacts. The morphological features of the unmodified pebbles were calculated following the Cailleux index (Cailleux 1951): $C_{i}=(L+I) / 2 E$, where $L, l$ and $E$ are the length, the width and the thickness of the pebble respectively. Different ranges of $C_{i}$ are sensible to specific types of secondary deposits defined by Cailleux as follows: 1,6-1,8 for moraines, 1-2 for fluvio-glacial deposits, 2,3-2,8 for marine beaches and 2,5-3,5 for fluviale deposits. 


\subsection{Manufacturing}

The labour force put in the preparation of the raw pieces can also be approached through the intensity of physical transformation previous to use. This aspect is directly related to the amount of transformation traces shown on the objects. This aspect was calculated through the Transformation index (Delgado-Raack 2008: 307) which is estimated as follows: $T_{i}=n$ transformed surfaces/n preserved surfaces. In this ratio the highest number would be 1 , which corresponds to a total transformation of the object, while 0 would correspond to an unmodified specimen. As this is a value exclusively related to transformation previous to use, active surfaces, accordingly covered by use-wear traces, have been ignored in the $T_{i}$.

\subsection{Use-wear analysis}

Once the artefact has been manufactured, it is ready to be used. In the case of macrolithic material, artefacts are commonly implemented as tools (work means) and sometimes as decorative elements (e.g., stone bead or stone pendant), building material (e.g., ashlar rock) or ritual elements (e.g., stone idol). Information about the function of the artefacts is given by their physical and chemical changes, leading to use-wear traces and residues, which can affect the whole artefact, at the level of general morphology, or part of it, at the level of an active surface.

Use-wear traces and residues remaining on the active surfaces of the artefacts, were described and evaluated macroscopically and under stereoscopic observation up to $60 \mathrm{x}$ magnifications with an Olympus Japan VM VMT loupe, following the standardized procedure for low power magnification presented by Delgado-Raack (2008: 184-226) and Adams et al. (2009: 43-66). This procedure is based on a long-term experimental research started in the 1990s and during which a large reference collection of use-wear traces has been accumulated including those coming from different food grinding processes, copper forging and polishing, leather work, pottery polishing, temper processing, and stone manufacturing. The rock types used cover a wide range of lithologies, such as different kinds of schists, slates, limestones, sandstones, conglomerates, quartzites, and gabbros. The evaluated usewear traces on experimental as well as on archaeological specimens are fractures of different manner, pits, striations and scratches, rounding, levelling, polish or sheen observed at macroand mesoscopic level (Adams et al. 2009: Tabs. 6.2 and 6.4). Although the format constraints of this paper do not allow to extent on this issue, these traces are systematically described elsewhere according to their distribution, density, incidence, morphology, disposition, orientation, metrics and reflectivity (Delgado-Raack 2008: fig. 2.2.26).

Another technique used in this study for a more precise characterization of this kind of evidence is a Keyence VHX-5000 digital microscope, which allows up to 5000x magnification and was used for measuring specific use-wear traces as small cupules (see below). Some stone surfaces, on which adherences were observed under the stereoscopic loupe, were characterized by pXRF through a Thermo Niton Analyzer LLC with the aim of determining the chemical composition of possible residues due to use, that is to say, due to the worked materials. The equipment implemented for the study of the macro-lithic material from Bruszczewo was available in the Graduate School Human Development in Landscapes and the Institute of Pre- and Protohistoric Archaeology of the Christian-Albrechts University of Kiel. 


\subsection{Analysis of spatial distribution}

Finally, all the information gained according to the technological and functional study (manufacture and use) of the macro-lithic tools was chrono-spatially evaluated through their spatial distribution in Mapinfo 8.0 GIS software. For the purpose of this paper, this was done for the tools coming from Early Bronze Age layers. This allowed setting the artefacts in their social context of production, in relation to structures and other materials, taking into account whether they were in process of manufacturing, using, recycling or discarding.

\section{Results}

The technological (raw material and manufacture analysis) and functional (use-wear analysis) characterization of the 1073 macro-lithic items coming from the site of Bruszczewo has resulted in the identification of 691 (64\%) unmodified and unused pebbles and stone fragments, and 382 (36\%) artefacts. Among the latter a remarkable variety of artefact types has been determined. The first and most numerous group is composed of well preserved small sized tools, which were used in different percussive tasks: percussors, picks, shaft-hole axes and flakes. The latter were the by-product of percussion activities or accidents (Figure 3). The second group includes artefacts affected by abrasive wear mechanisms. These are large tools, such as grindingslabs, rubbers and stoneslabs, all of them badly preserved, as well as small tools, like abraders and sharpeners, most of them complete. A third well defined, although quantitatively limited group, is represented by small, morphologically varied platforms on which specific activities were performed involving some kind of percussion or pressure. These are anvils and pierre à cupule, depending on the purpose of these activities and the morphology of the contact material, which was an extense surface in the first case or a stinging object, in the second. The high amount of the so called multifunctional artefacts, involved in multiple activities, is also noteworthy. These can be related to up to all three types of wear mechanisms macroscopically recognizable: abrasion, percussion and or an association of both wear mechanisms, percussion and pressure. All of them show a good preservation level. Even though, it is noteworthy that no substantial differences have been recognized in the representation of tool types during the different occupation phases.

In this section the macro-lithic assemblage is presented regarding its raw material, manufacture and use.

\subsection{Raw material supply}

Most of the 382 artefacts recovered in the wet soil area of Bruszczewo were originally pebbles, according to their remaining naturally eroded surface. This is recognizable thanks to the minimal manufacturing process applied on them. In this regard, 691 unworked and unused pebbles and stone fragments have been crucial to define the raw material supplying system developed during the occupation of the settlement. The main rock types determined among the unmodified pieces are, in descendent order of frequency, quarzitic rock, granitic rock, gneiss, sandstone and gabbro. Other rocks as conglomerate, limestone, volcanic rocks, micaceous schist, slate and flint were recorded in significantly lower number. The specific spherical proportions measured for the unmodified pebbles through the Cailleux index (Cailleux 1951) indicate we are dealing with products of fluvio-glacial transport processes (Figure 4).

As these unmodified pebbles appear spatially associated to macro-lithic artefacts in the site, it is likely to assume that some of them could stand for raw material, susceptible of being transformed into a tool. 


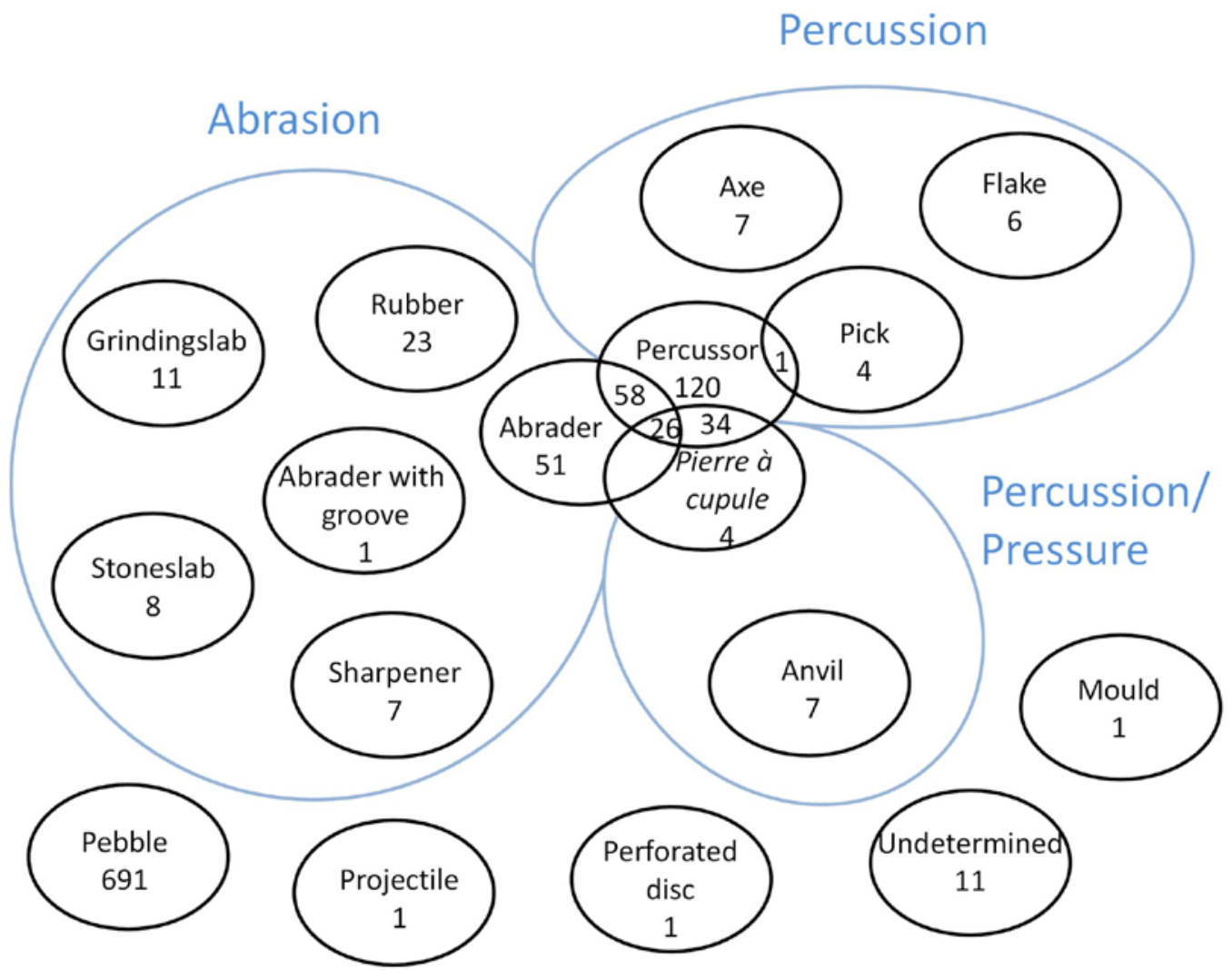

Figure 3. Absolute quantities of different macro-lithic items recovered in the wet soil area of Bruszczewo (above), and their percentage frequencies in each of the occupation periods of the site (below). Note the considerably high amount of multifunctional artefacts resulted from the combination of abraders, percussors and, or, pierre à cupules. In the above graphic artefacts are grouped according to the main wear mechanisms macroscopically recognizable on their active surfaces, which are the basis for the subsequent use-wear analysis. (See Table 2.)

Table 2. Data from Figure 3.

\begin{tabular}{|c|c|c|c|c|c|c|}
\hline & \multicolumn{2}{|c|}{ Early Bronze Age } & \multicolumn{2}{|c|}{$\begin{array}{l}\text { Late Bronze Age } \\
\text { Early Iron Age }\end{array}$} & \multicolumn{2}{|c|}{$\begin{array}{l}\text { Colluvium up to Middle } \\
\text { Ages and Mixed layers }\end{array}$} \\
\hline & $\mathbf{N}$ & $\%$ & $\mathbf{N}$ & $\%$ & $\mathbf{N}$ & $\%$ \\
\hline Flake & 3 & 2,33 & 0 & 0 & 3 & 2,07 \\
\hline Axe & 3 & 2,33 & 1 & 0,93 & 3 & 2,07 \\
\hline Pick & 0 & 0 & 2 & 1,85 & 2 & 1,38 \\
\hline Percussor & 36 & 27,91 & 35 & 32,41 & 49 & 33,79 \\
\hline Rubber & 10 & 7,75 & 5 & 4,63 & 8 & 4,83 \\
\hline Grindingslab & 4 & 2,33 & 3 & 2,78 & 4 & 2,07 \\
\hline Stoneslab & 3 & 2,33 & 2 & 1,85 & 3 & 2,07 \\
\hline Abrader & 18 & 13,95 & 14 & 12,96 & 19 & 13,10 \\
\hline Abrader with groove & 0 & 0 & 0 & 0 & 1 & 0,69 \\
\hline Sharpener & 1 & 0,78 & 1 & 0,93 & 5 & 3,45 \\
\hline Pierre à cupule & 2 & 1,55 & 2 & 1,85 & 0 & 0,00 \\
\hline Anvil & 3 & 2,33 & 2 & 1,85 & 2 & 1,38 \\
\hline Mould & 0 & 0 & 0 & 0 & 1 & 0,69 \\
\hline Projectile & 0 & 0 & 0 & 0 & 1 & 0,69 \\
\hline Perforated disc & 0 & 0 & 0 & 0 & 1 & 0,69 \\
\hline Undetermined & 5 & 3,88 & 4 & 3,70 & 2 & 1,38 \\
\hline Multifunctional tools & 41 & 32,56 & 37 & 34,26 & 41 & 29,66 \\
\hline Macro-lithic artefacts (total $\mathbf{n}_{1}$ ) & 129 & 100 & 108 & 100 & 145 & 100 \\
\hline Unmodified \& unused pebbles $\left(\mathrm{n}_{2}\right)$ & \multicolumn{2}{|c|}{278} & \multicolumn{2}{|c|}{151} & \multicolumn{2}{|c|}{262} \\
\hline Macro-lithic items (total $n_{3}=n_{1}+n_{2}$ ) & \multicolumn{2}{|c|}{407} & \multicolumn{2}{|c|}{259} & \multicolumn{2}{|c|}{407} \\
\hline
\end{tabular}




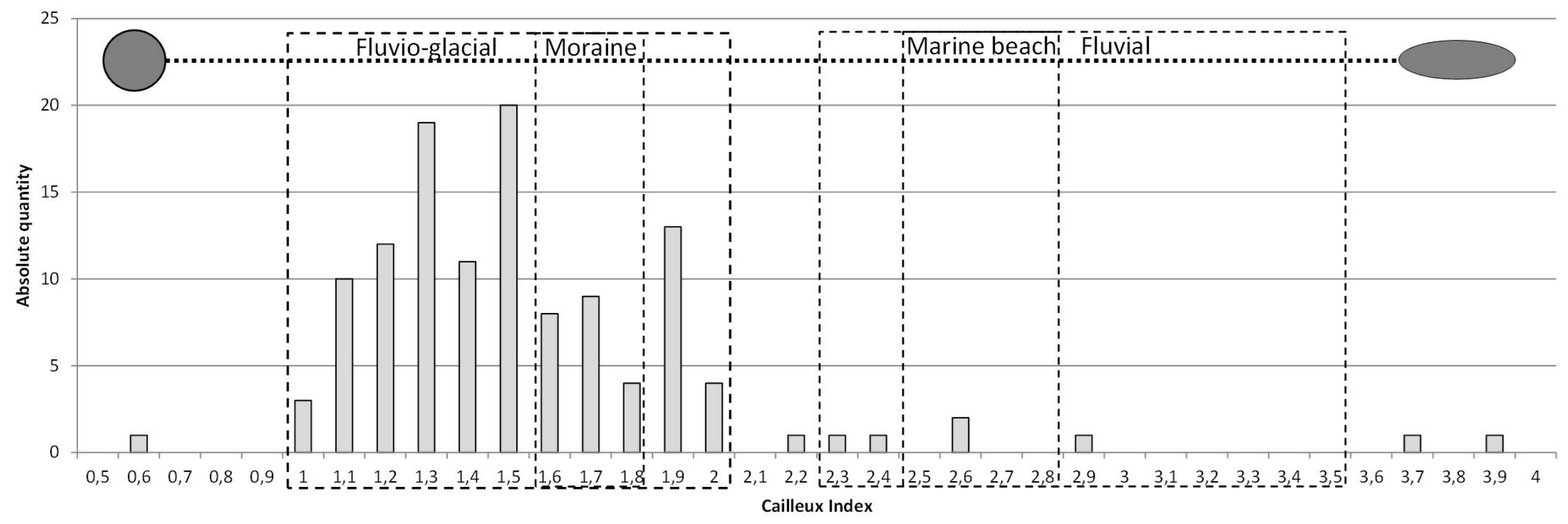

Figure 4. Absolute frequencies of the Cailleux indexes (Cailleux 1951) estimated on the basis of all unmodified pebbles recovered in the wet soil area of Bruszczcewo. 
The correlation matrix of the frequencies of each rock type in both groups, the unmodified pebbles and the macro-lithic artefacts results in a high correlation index (0.782) that stands for a probable common origin (Figure 5). Consequently, most of the raw materials of the macro-lithic artefacts could be obtained easily in fluvio-glacial deposits, which indeed were naturally available in the inmidiate sorroundings of the site (Hildebrandt-Radke 2010: 23; Bork 2010: 39ff). This allows defining a mainly local raw material supplying system, based on the gathering of pebbles in the vicinity. This pattern is a general trait of Bruszczewo, regardless of the occupation period (Early Bronze Age, Late Bronze Age and Early Iron Age).



Figure 5. Percentual frequencies of different rock types determined for all artefacts and unmodified and unused pebbles excavated in the wet soil area of Bruszczewo. (The scale bars are $5 \mathrm{~cm}$ wide, in $1 \mathrm{~cm}$ segments.)

Among the artefacts the most used raw materials are quarzite and quartz-rich rocks (quartz, metapsammite, siliceous limestone), which make up to $60 \%$ of the exploited rocks. This means that in general terms, mechanically hard rocks were prioritized over more abrasive materials, which were also available near the settlement. Even in the case of abraders, almost $50 \%$ were produced on quarzite and quarz-rich materials. However, there is no clear raw material specialization among most of the artefact types found in Bruszczewo. Only grinding equipment composed by grindingslabs and rubbers was mainly manufactured out of granitic stones (more than $75 \%$ of the grindingslabs and almost $50 \%$ of the rubbers), which are much more abrasive than quarzite due to the coexistence of glimmer, quarz and feldspar, that is to say, minerals offering different mechanical behaviour. As a result, beyond the general selection of rather hard materials for the macro-lithic artefacts, there is no specific standarization in the way raw materials are associated with artefact types, except in the case of grinding equipment.

In sum, the community inhabiting Bruszczewo did not need to invest much effort in obtaining raw material. Most of the time would have been spent on the accurate selection of appropriate pieces for the production of the intended tools among a wide variability of rock types, morphologies and sizes, rather than searching for one specific lithology. This initial raw material selection would have also favoured a minimal modification of the natural pebbles (see Section 3.2). 


\subsection{Manufacturing}

No preference has been recognized between artefact types and particular morphologies and there is even little evidence for an intentioned transformation of natural pebbles in order to obtain certain morphologies. This observation is supported by the Tranformation index, which includes the relation existing between preserved surfaces and transformed surfaces previous to use (Figure 6). In the case of most of the artefacts, there was minimal preparation or retouching of the raw piece before its use. Therefore, the manufacturing requirements for an optimal functioning of the artefacts can be considered as low, with almost no necessity for modifying the pebbles.

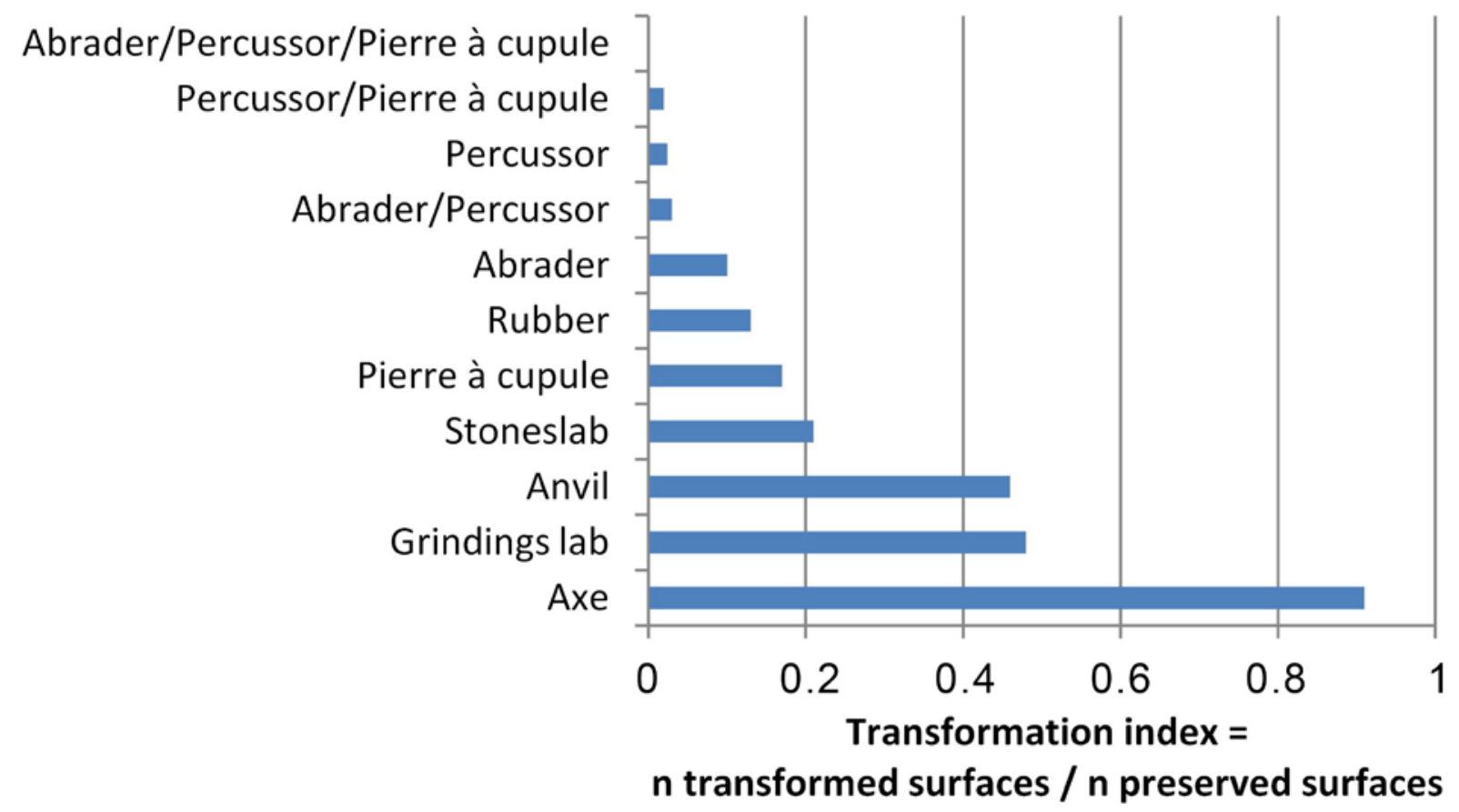

Figure 6. Transformation index of the most abundant artefact types recorded in the wet soil area of Bruszczewo, exposed in ascending order.

However, there are some exceptions for this low investment in the manufacturing of macro-lithic tools. Shaft-hole axes, grindingslabs and anvils show proportionally higher indexes of transformation, linked not only to their outfitting previous to use, but also to the will to extend their use life (Figure 6). Shaft-hole axes are the most invensively transformed artefacts in the site, as they were perforated and their cutting edges and surfaces were totally polished. Different stages in the use life of axes have been recognized, like roughouts, used and already broken artefacts as well as pieces that were just being perforated before they were abandoned in the site. The retouching of grindingslabs took place before and after the tool started to be used. Their active surface would have to be periodically pecked for the maintenance of the apropriate roughnes for grinding, as well as its borders, which were chopped with the aim of soften the angles and reinforcing the robustnes of the tool. Finally anvils show an active surface, which was carefully abraded and polished before use in order to make possible the forging of metal objects without breaking them. Additionally in many cases they were sorrounded by abraded facets, which soften the angle avoiding breaks of the surface while blowing with the hammer against the anvil. In the studied assemblage no forging hammers, which could have acted as the reciproque tools of anvils, have been recovered up to date. Honig (2004: 255) quotes a fragment of an axe, that in his opinion could 
have participated in metalworking. The highly developed wooden technology recovered in the site makes it likely that wood maces or even antler hammers instead of stone hammers could have been used (Kneisel \& Kroll 2010: 576-661).

Apart from the mentioned macro-lithic tools, there is a small group of artefacts that show manufacturing but no use wear traces (Figure 3). This group comprises a casting mould, which is clearly affected by termal alteration (as the only evidence of use), a perforated disc and a possible projectile stone. These pieces should also belong to the most intensively transformed ones.

\subsection{Use}

The observation of the active surfaces of the tools by naked eye has allowed to do a first and general classification of the macro-lithic artefacts according to the abrasion, percussion and, or, pressure mechanisms affecting their active surfaces. Moreover, under certain magnification, and, in some specific cases, also through the compositional characterization of adherences, it was possible to suggest a function for some macro-lithic tools or, at least, a functional hypothesis.

The first group of tools is functionally related to food processing, from which the clearest evidence is grinding. Grinding slabs in Bruszczewo were used in reciprocal motion with rubbers. The frictional contact between two stone bodies is shown in the use-wear analysis through the presence on grinding surfaces of intensively levelled areas surrounded by a more or less intact lower topography (Figure 7A-B). Striations often occur on these levelled areas, longitudinally oriented in the case of grindingslabs and transversally oriented on rubbers. They are intermittent and appear interrupted by anfractuosities and, or, by the effects of the third body acting between both stone surfaces. In comparison to grinding artefacts, stoneslabs are more slightly worn. In contrast, the variability of use-wear traces is larger than in the artefacts specifically used for grinding. As a result, stoneslabs should be interpreted as platforms for processing a variety of food, such as vegetables or meat using not only grinding but also different procedures, such as cutting or pounding. On food processing tools no residues analysis (fitoliths of starch) has been undertaken so far, even if vegetal remains, such as Hordeum and Triticum dicocum are widely documented in Bruszczewo (Kneisel 2010a: 912).

A further functional group is composed of bevelled artefacts, which are appropriate for cutting, piercing or stripping. All were perforated for shafting with the bevel oriented parallel to the handle. Where the active surface is still remaining, remarkable edge damage has been observed. Most of the edges are considerably blunt and rounded, showing not only heavily pecked surfaces and loss of material but also stepped fractures (Figure 7C-D). This makes them totally unsuitable for wood working. In this sense, it is possible that they had been reused for blowing against a harder material than wood, which was responsible for the intense wear of the edges.

The next group includes a large quantity of artefacts which participated in several tasks involving percussion, abrasion and pressure (percussors, abraders, pierre à cupule). Many of them can be considered as multifunctional tools, because they often combine different usewear traces in one and the same piece. The main use-wear traces observed are (a) cracks and pits, which form clearly visible blunt facets (Figure 7E-F), (b) levelling, and (c) striations and loss of grains. According to the qualitative patterns mentioned it should be concluded that these artefacts were used in contact with rather hard materials in order to break, crash or transform them through friction. It is likely that they participated in the processing of raw material of mineral origin, such as stone knapping, preparing of temper or pottery polishing. Their involvement in the crushing of animal products such as bone is also thinkable. 


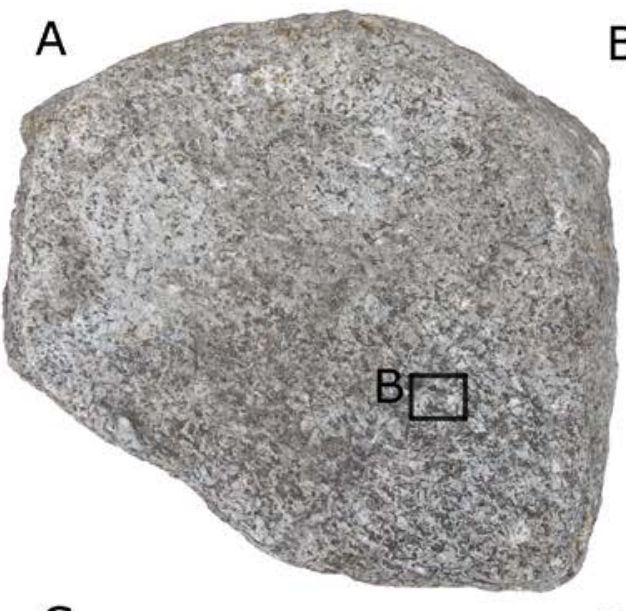

\section{B}

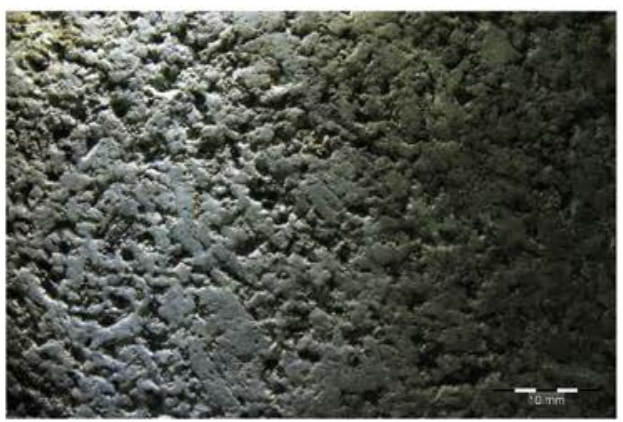

C

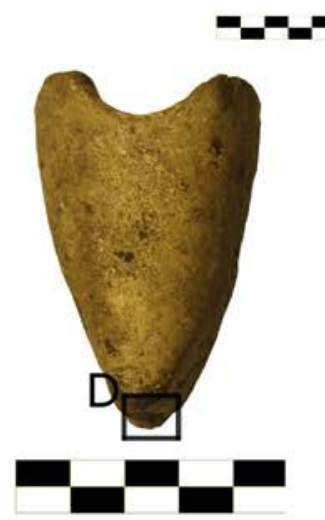

D

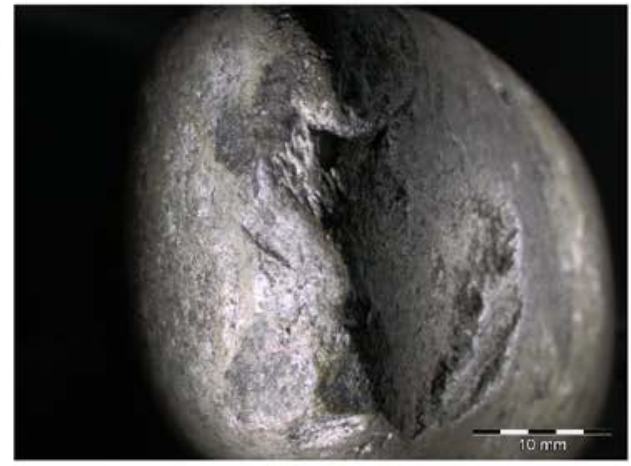

E

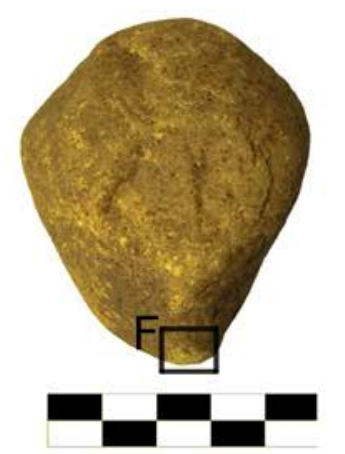

F

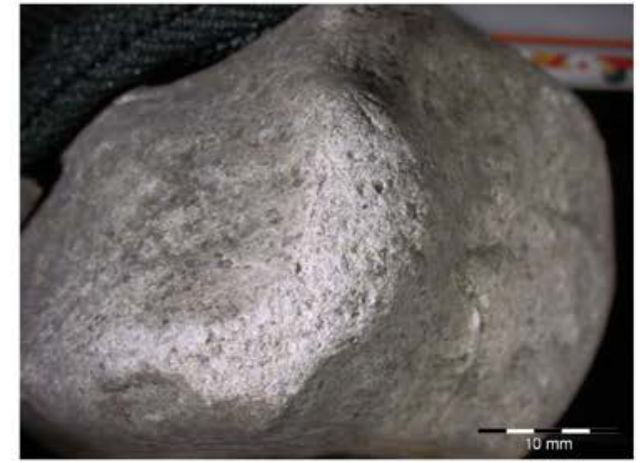

\section{G}

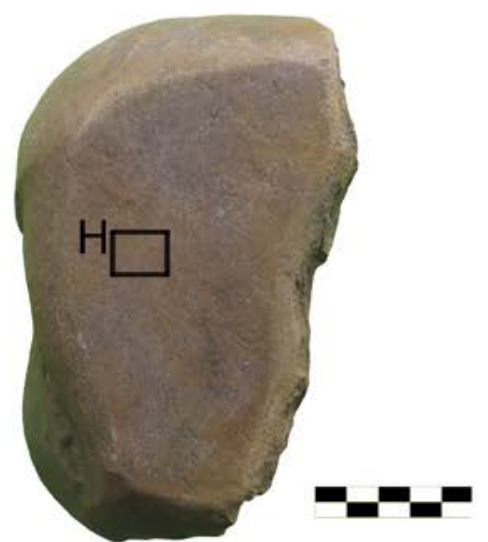

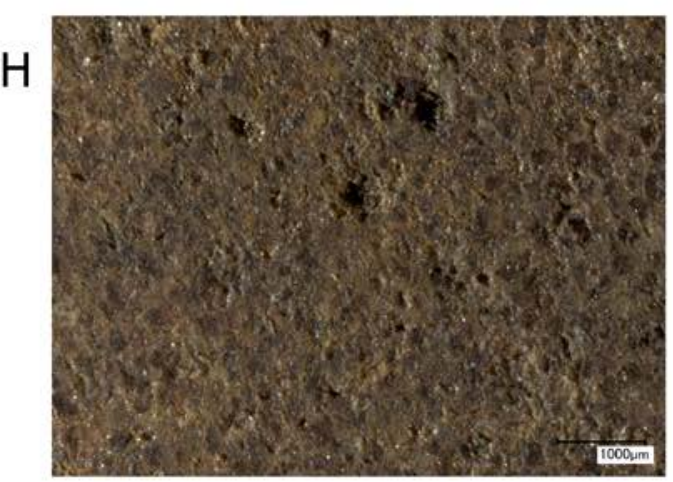

Figure 7. Selection of macro-lithic artefacts recovered in Early Bronze Age layers from Bruszczewo. A-B) Fragment of a grindingslab with intensive levelling on the active surface and intact anfractuosities in between. CD) Shaft-hole axe showing a totally damaged bevel covered by stepped fractures. E-F) Percussor with a facet located on the bottom edge of the pebble and affected by pecking. G-H) Anvil showing a totally flat and shiny forging surface prepared previously to use through smoothing and rounding of edges in the periphery. 
Percussors, abraders and the multifunctional artefacts, seem to have had an opportunistic use since there is no difference between wear intensity, location of active surfaces, dimensions of use-wear traces or type of percussion traces. Percussion and abrasion traces are located on wide surfaces as well as on edges or even vertexes. Only the tasks developed with the aid of the pierre à cupule show a characteristic use-wear pattern which can be linked to a specific functionality. Use-wear traces always appear in the centre of wide regular surfaces, with convex, straight or even concave profile. In this case, very shallow cupules or scars are more or less scattered covering a narrow area, which does not exceed more than 37x36 mm and $1 \mathrm{~mm}$ in depth. They form patterns that range from disconnected singular pits (Figure 8, A-B), which nonetheless maintain certain spatial coherence between each other, to more complex patterns of juxtaposed pits (Figure 8D-G). On the one hand, similar wear patterns have been observed on very ancient macro-lithic artefacts interpreted as "compressors" or retouching tools against which flint flakes were pressured (Delgado-Raack 2011: 171-196). However, the technologically most complex flint artefacts known in Bruszczewo are arrowheads, showing bifacial negatives (Budziszewski 2015: 243-248; Kryszowski 2015: 249-282), a kind of retouching that needs other technological procedures. Another functional interpretation for this kind of artefacts could be related to the last stages of metallurgical production, such as for example perforating metal sheets, elaborating or fixing rivets in the basis of metal blades. A total amount of 27 such artefacts were subjected to pXRF analysis to track remaining adherences in the interior of the cupules. In one case very small quantity of copper was found, among other chemical elements. In front of the possibility that metal objects could have come into contact with metal surfaces, the mentioned manufacturing procedures should be experimentally tested and analysed in the future.

Although at this point it is difficult to specify the actual functionality of the pierre à cupule, it is likely that highly accurate tasks were performed with them according to the features described. Even if these artefacts are not technologically standardized (regarding lithology, morphology, etc.), the way the cupules evolve during use follows a concrete pattern which indicates that we are probably in front of a "static" tool rather than a mobile one taken by the hand. The assessment of digital images allowed observing that the depth of the pits does not increase when the cupule expands (Figure 8E and G). This means that once a certain scattering of pits was reached, the task was given up, with no expansion beyond its limits. As a result, it is highly probable that users controlled where to place the contact material to be worked.

Similar to the pierre à cupules, anvils were also used as "static" tools or small platforms. However, unlike the former, evidence of the use of anvil do not coexist with other kind of use-wear, since the whole artefact was conceived as a highly specialized tool, only devoted to the forging of metal objects. In this case, results derived from the interpretation of use-wear traces were confirmed through residues analysis developed with the aid of a systematic sampling strategy (Delgado-Raack 2018). Three out of the seven anvils recorded in this study underwent pXRF analysis and all of them had still metallic adherences remaining. Two of them contained copper remains (Figure 7G-H), while the third one had copper, gold and silver remains. This result connects the anvils used in Bruszczewo to the forging of copper as well as gold objects with a high silver content. The data of this analysis will be published elsewhere (Delgado-Raack 2018; Müller et al. 2020). 

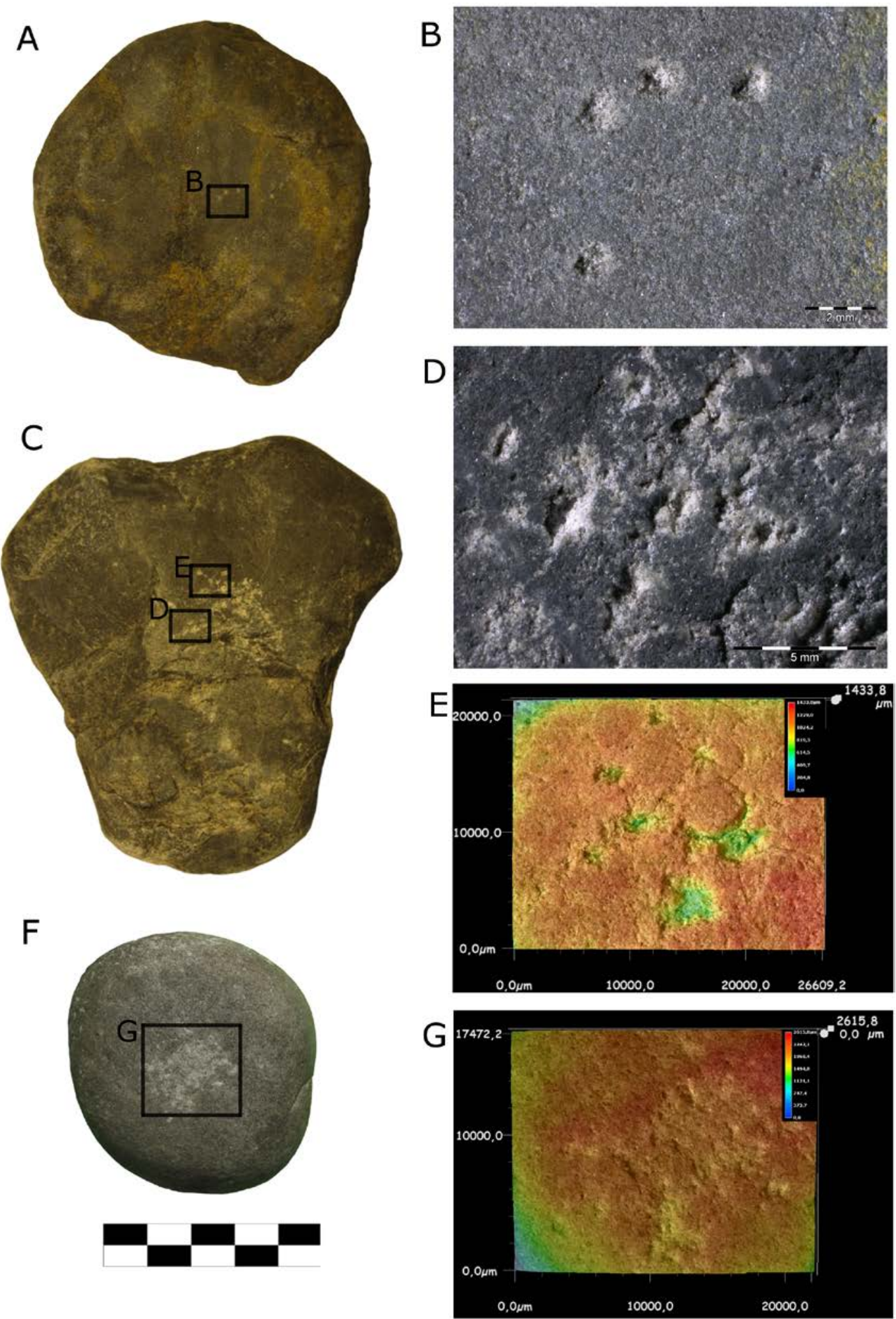

Figure 8. Macro- and mesoscopic aspect of artefacts used as small platforms on which accurate tasks were performed involving percussion and pressure mechanisms. Pictures in the right show the development of small and shallow pits forming slight cupules in different stages of use. A-B) Artefact in an incipient stage of use, with single pits in a curved disposition. C-E) Artefact in a slightly developed stage of use characterized by an emerging cupule; D) in the periphery of the central concentration single pits are still recognizable forming in some cases cross-like patterns; F-G) fully developed cupule with juxtaposed pits which cannot be individualized anymore. Pictures $\mathrm{E}$ and $\mathrm{G}$ were made under the digital microscope and show that the most complex pattern does not imply necessarily a larger depth of the cupule. 


\subsection{The spatial distribution of macro-lithic tools in the Únětice period}

At the beginning of the Unětice period a fortified settlement was built on the top of the hill covering an extension of 0.9 ha, from which 0.4 ha have been excavated so far. The fortification is formed by a $20 \mathrm{~m}$ wide and $4 \mathrm{~m}$ deep ditch with double palisade and a wall, defending the settlement from the Hinterland located to the north, south and west. On the highest area of the hill a total number of 10 synchronic houses could have stand taking into account the morphology of the long pits. Fireplaces and other round pits were also excavated, but were not necessarily associated with houses. From about $1800 \mathrm{cal}$. BCE on the settlement expanded to the east, reaching the water shore, where a fascine was built. In the area within the fascine at least four houses of ca. $8 \times 5 \mathrm{~m}$ stood, occupying the bottom area of the hill.

From the described contexts of the wet soil area a total number of 129 macro-lithic tools have been studied so far belonging to the Únětice occupation. The use of artefacts such as percussors, abraders and pierre à cupule was very common in the site, as they were widely scattered over the whole area (Honig 2004: 247-256), no one predominating clearly among others. These small but highly resistant tools were probably managed directly in the hand and could have served for multiple purposes as suggested in the previous section. In the case of pierre à cupule specific tasks related to the final stages of metallurgical production could be mentioned, although it has already been stated above that this possibility should be experimentally confirmed.

The domestic food preparation was done by grindingslabs, rubbers and stoneslabs, for which spatial data exist also for artefacts coming from other areas of the settlement (Kneisel \& Müller 2011: Abb. 8). Taking into account the distribution of such artefacts in the wet soil area as well as in the mineral soil area, there is a scattering of them in both parts of the site (Figure 9). In general terms, there is no evident concentration of artefacts neither in the structures nor in open areas. Besides the labour means destined to the processing of food, positive evidence of grain storing has been found in one of the houses located in the wetland area, where waterlogged conditions must have favoured its preservation. Grain may have been also stored at least in some of the numerous pits used in the top of the settlement. Whether the artefacts found immediately nearby the fascine were or not in an operative stage remains unclear: those recorded in the current study are very badly preserved (fragments) and could represent tools reused as raw material for temper (Honig 2004), discarded elements or even stepping stones in the lake side.

The only noteworthy concentration documented in the spatial analysis of macro-lithic tools are the three axes, which are located near the water, in a placement interpreted as a workshop for manufacturing bone and antler tools (Figure 9) (Kneisel \& Müller 2011: Abb. 19). The intense damage of their bevels, as mentioned in the previous section, together with the specificities of the archaeological context suggest that their function was not linked to wood working, but to the transformation of bone and antler. 


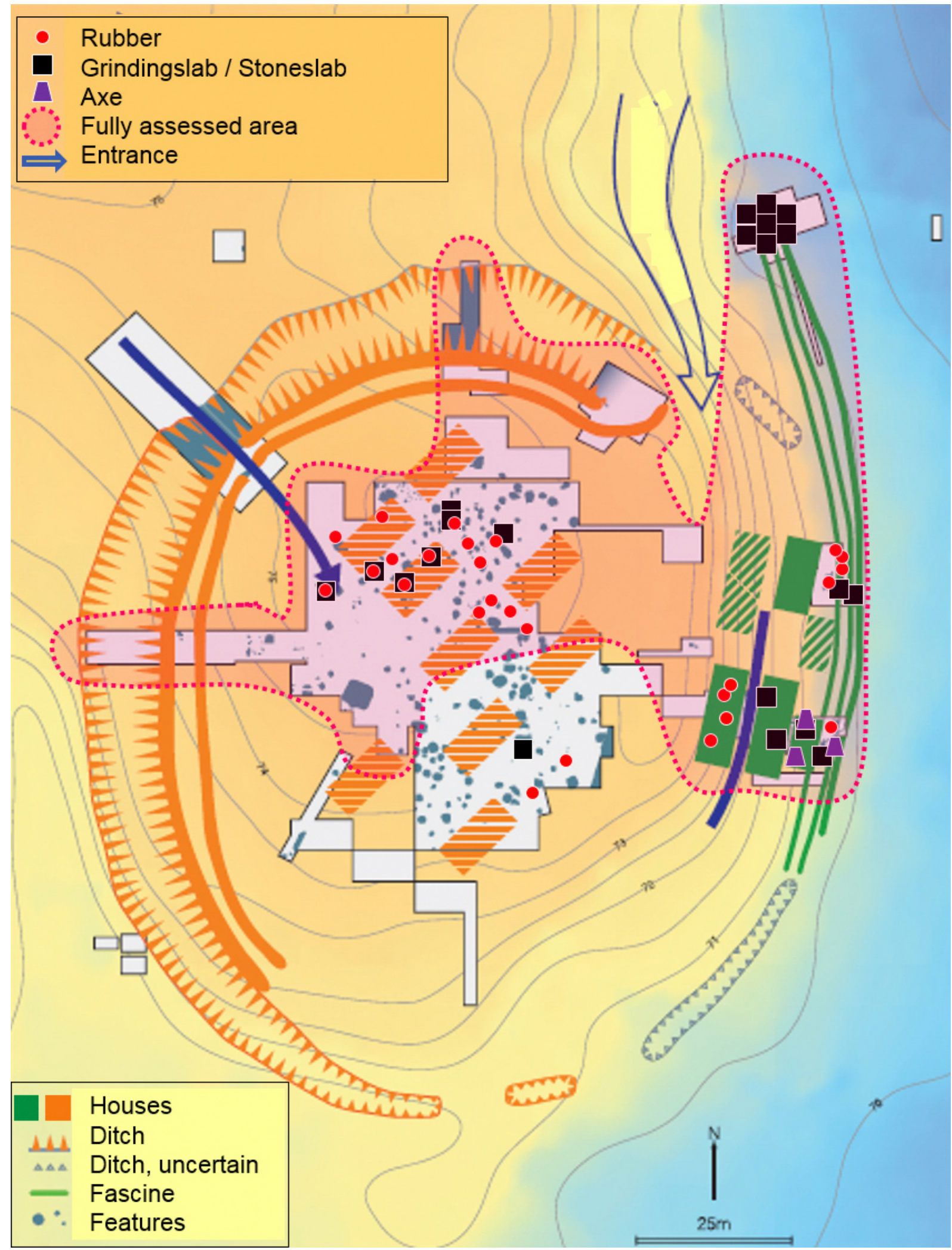

Figure 9. Spatial distribution of food processing macro-lithic tools (grindingslabs, rubbers and stoneslabs) and axes attributed to the Únětice occupation of the site (based on Honig 2004 and Kneisel \& Müller: 2011: Abb. 8 and updated). One dot represents one tool.

Other productive evidence available for the site show some differences between the mineral soil and the wet soil area (Table 3). Faunal remains indicate that when it comes to pork processing, this activity was sharply limited to the higher area of the settlement (Kneisel 
2010a: 1-18; Kneisel \& Müller 2011: 295-324). On the contrary, wild animals were slaughtered only near the water (Table 3 ). The wet soil area was devoted to all manufacture processes documented so far in Bruszczewo except probably metallurgy. Up to date no clear casting evidence has been found in the water logged area. The only casting mould known for this part of the settlement belongs to a mixed layer with Early and Late Bronze Age materials. In the case of the three forging anvils attributed to Únětice layers they are linked to the basis of the stratigraphy, appear re-deposited in structures such as stone settings for posts or remain preserved in a very fragmented stage. This fact suggests that these anvils came from use contexts located at the top of the hill and were also discarded in this context. Despite the absence of remains related to metallurgical production, the use of the metal objects each self, reached also the wet soil area, leaving aside the possibility mentioned before that the pierre à cupule could have participated in the last stages of metallurgical production.

Table 3. Main productive tasks documented during the Únětice occupation in Bruszczewo. * activities also evidenced by the macro-lithic artefacts.

\begin{tabular}{|c|c|c|c|c|}
\hline Recorded activities & $\begin{array}{l}\text { Mineral } \\
\text { soil area } \\
\text { (plateau) }\end{array}$ & $\begin{array}{c}\text { Wet } \\
\text { soil area } \\
\text { (lake side) }\end{array}$ & $\begin{array}{l}\text { Basis economic } \\
\text { scheme }\end{array}$ & $\begin{array}{l}\text { Type of } \\
\text { production }\end{array}$ \\
\hline $\begin{array}{l}\text { Food processing } \\
\text { (grain and others) * }\end{array}$ & $x$ & $x$ & $\begin{array}{l}\text { Immediate } \\
\text { consumption }\end{array}$ & Subsistence \\
\hline $\begin{array}{l}\text { Slaughtering of } \\
\text { domestic animals }\end{array}$ & $x$ & $x$ & $\begin{array}{l}\text { Immediate or long- } \\
\text { term consumption }\end{array}$ & $\begin{array}{l}\text { Subsistence or } \\
\text { manufacture }\end{array}$ \\
\hline Pork processing & $x$ & & $\begin{array}{l}\text { Immediate or long- } \\
\text { term consumption }\end{array}$ & $\begin{array}{l}\text { Subsistence or } \\
\text { manufacture }\end{array}$ \\
\hline $\begin{array}{l}\text { Slaughtering of wild } \\
\text { animals }\end{array}$ & & $x$ & $\begin{array}{l}\text { Immediate or long- } \\
\text { term consumption }\end{array}$ & $\begin{array}{l}\text { Subsistence or } \\
\text { manufacture }\end{array}$ \\
\hline Grain storing & & $x$ & $\begin{array}{l}\text { Long-term } \\
\text { consumption }\end{array}$ & Subsistence \\
\hline $\begin{array}{l}\text { Textile and leather } \\
\text { manufacture }\end{array}$ & $x$ & $x$ & $\begin{array}{l}\text { Long-term } \\
\text { consumption }\end{array}$ & Manufacture \\
\hline Use of metal tools & $x$ & $x$ & $\begin{array}{l}\text { Immediate } \\
\text { consumption }\end{array}$ & $\begin{array}{l}\text { Subsistence or } \\
\text { manufacture }\end{array}$ \\
\hline Metal working* & $x$ & & $\begin{array}{l}\text { Long-term } \\
\text { consumption }\end{array}$ & Manufacture \\
\hline $\begin{array}{l}\text { Bone and antler } \\
\text { workshop* }\end{array}$ & & $x$ & $\begin{array}{l}\text { long-term } \\
\text { consumption }\end{array}$ & Manufacture \\
\hline Wood working $\left({ }^{*}\right)$ & & $x$ & $\begin{array}{l}\text { Long-term } \\
\text { consumption }\end{array}$ & Manufacture \\
\hline Pottery making $\left({ }^{*}\right)$ & & $x$ & $\begin{array}{l}\text { Long-term } \\
\text { consumption }\end{array}$ & Manufacture \\
\hline Ritual practices* & $x$ & $x$ & \multicolumn{2}{|c|}{ Discard } \\
\hline Discarding* & & $x$ & \multicolumn{2}{|c|}{ Discard } \\
\hline
\end{tabular}

In contrast to the wide variety of manufacturing tasks near the water, the top of the hill was devoted to textile and leather manufacture (according to the study of the animal remains), and metallurgical work processes (Kneisel 2013: 173-198). Metallurgical activities are evidenced in this area through metal finished objects (tools, weapons as well as ornaments), labour means such as a ladle, tuyères, a crucible, one half of a sandstone mould and discarded 
materials such as droplets and scraps. In the western part of the mineral soil area, a casting place was recovered during the excavations of the 60s, while more recent works show that most of the metal findings are located in the southern part of the excavated mineral area (Jaeger et al. 2015: 227-234).

Finally, in Bruszczewo there is evidence of amortization of tools from which the most interesting element is ritual practices. Ritual events took place at the top of the settlement as well as near the lake shore and were of different kind. Some human bones were preserved from pits as well as the lake layers, but they all remain without any visible burial context (Jaeger et al. 2016: fig. 4). The only grave known until now in Bruszczewo was placed in the wetland area and it included an inhumation of a male, who had carried heavy loads on his shoulders and head, according to osteological analysis (Iwanek et al. 2010: 731-753; Kneisel 2010b: 725-729; Jaeger et al. 2016). Two macro-lithic artefacts made of quartzite and a stoneslab made of granite were put in the burial and at his feet, all of which had been used as tools previously to the deposition (Figure 10). While the former were used for multiple purposes related to abrasion, percussion and pressure, the stoneslab probably served as a platform for processing food. Opposite to this rather poor grave, a completely different context, regarding its conception and content, was intentionally deposited at the top of the settlement, near the casting place. This deposit was a hoard including two metal axes and a damaged dagger blade (Czebreszuk et al. 2004: 19; Jaeger et al. 2015: 228), which stands close to the content of other known hoards in the region of Kościan and grave goods found in princely barrows (Łęki Małe and Przysieka Polska; Schwenzer 2004: 317-329) located a few $\mathrm{km}$ far away from the site.

\section{Discussion and conclusions}

The technological and functional study of 1073 macro-lithic items recovered in the wet soil area of Bruszczewo allows defining a production system based on the local supply of rocks coming from fluvio-glacial deposits for each occupation period of the site. The lithological specialization among tools can be considered as low, although rather hard materials such as quartzitic rocks were prioritized. Only the production of grinding equipment was based principally on more abrasive granitic rocks.

The manufacturing of macro-lithic tools is characterized by a high opportunistic way of selecting and transforming the natural pebbles, as several morphological features coexist within one and the same artefact type. Most of them have remained unmodified, appearing use-wear traces as the only evidence of production. The opportunistic character of the artefact manufacturing is consistent with the high frequency of multifunctional tools combining abraders, percussors and pierre è cupule.

The technological and spatial analysis developed specifically for the Únětice tools show an apparent homogeneity in the managing of subsistence resources (food) in the settlement through the wide scattering of rubbers, grindingslabs and stoneslabs. Also, smaller artefacts as abraders, percussors, pierre à cupule and multifunctional tools derived from them seem to have been equally distributed. No substantial differences nor concentrations could be recognized among the distribution of these tools in the site. On the contrary, some spatial variations appear in the distribution of tools related to specific manufacturing processes. Firstly, axes were concentrated in the area nearest to the water, in a workshop in which bone and antler objects were produced. Secondly, all three anvils recovered in the wetland area seem to come from the mineral soil area. In fact, at least casting and forging of metal objects could have taken place exclusively on the top of the hill, where a casting place and a hoard were located as well as several metallurgical debris scattered across the hill. According to these observations and others related to the restricted consumption of animals, the 
manufacturing of wood, textiles, bone and antler, we can ascertain that spatial segregation existed during the Early Bronze Age in Bruszczewo. This is also suggested by the presence of a rather poor grave with an injured male in the wetland area, which is clearly opposed to the rich hoard deposited on the top of the hill.
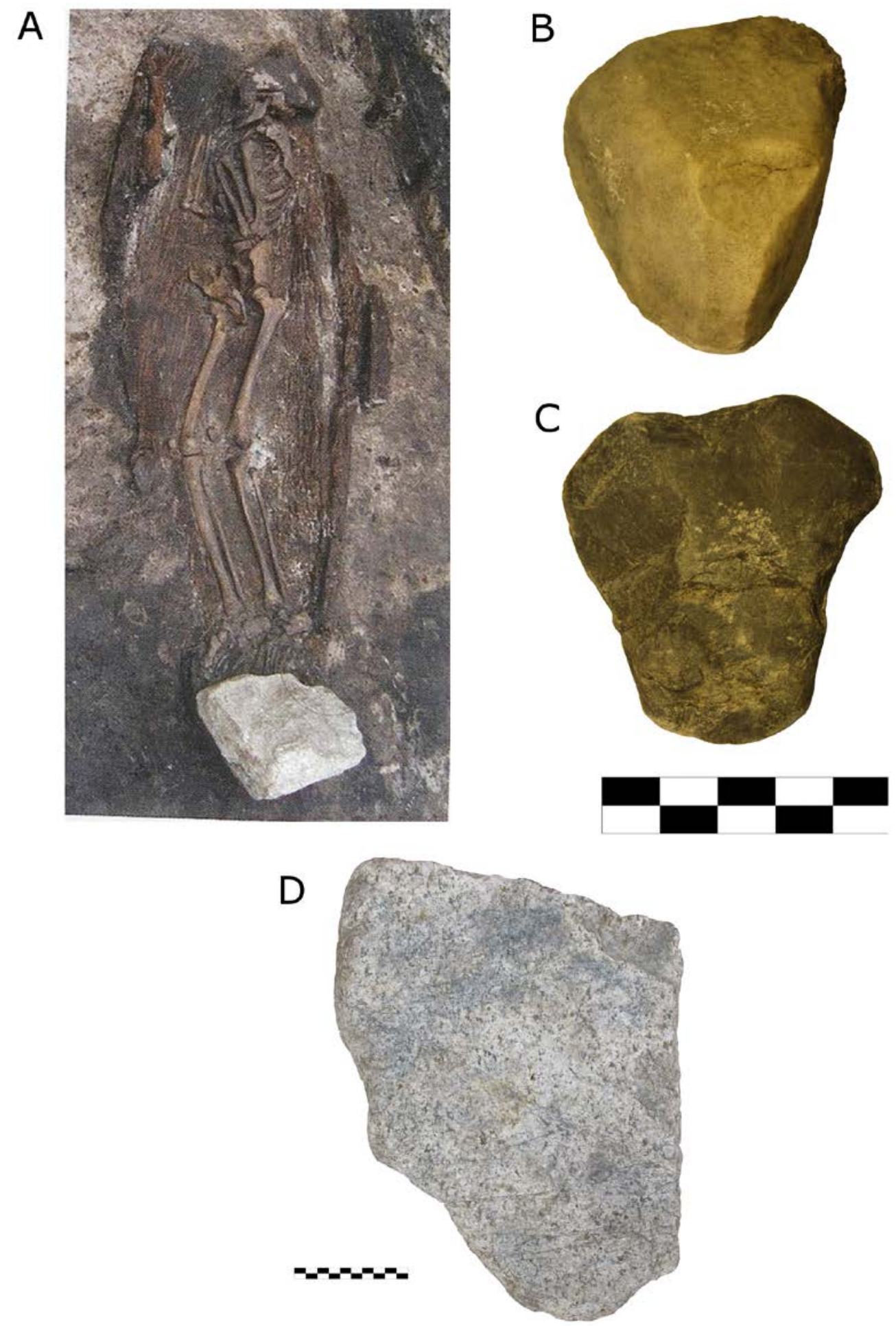

Figure 10. A) Grave found in the wetland area of Bruszczewo in which macro-lithic artefacts were given as the only grave goods in this context (taken from Kneisel et al. 2012: 22). B-C) macro-lithic artefacts made of quartzite and used for multiple purposes according to their use-wear traces. D) stoneslab made of granite, found at the feet of the deceased. This finding represents the only funerary context known in Bruszczewo so far. 
At a general level, the metallic residues documented on some anvils prove the direct participation of Bruszczewo in the forging of copper and gold objects, which must be related with mechanisms of social hierarchy and power reflected in the rich princely graves of the Kościan region (Łęki Małe). The settlement did not have a privileged geographical position regarding access to valuable raw materials such as copper, gold or amber. Still, it acted as a central settlement in the wide network established in the eastern outskirts of the Únětice territory, through which exogenous raw materials, finished objects and knowledge about specific casting techniques were exchanged and spread. Even if compositional analyses of the metal of Łęki Małe are still to be performed, it is very likely that gold and copper objects deposited in these graves were produced in Bruszczewo. In this sense, the management of the production system was done by the settlement appropriating materials naturally absent in the region of Kościan, producing objects made out of these distant raw materials and redistributing them to restricted groups of the Únětice society. All these aspects were critical in the consolidation and securing of the production system in which Bruszczewo participated as a nuclear site controlling not only the exchange of valuable objects but also distant raw materials and their transformation in objects and goods. These differences can be interpreted as necessary in order to maintain the status quo of the elites inhabiting Central Europe during the Early Bronze Age.

\section{Acknowledgements}

We would like to thank the Kiel Graduate School 'Human Development in Landscape' (DFG-GSC208), the Collaborative Research Centre 'Scales of Transformations in prehistoric and Archaic Societies' (DFG-SFB 1266) and the project "North Unetice: Late Neolithic/Early Late Neolithic Bronze Age developments in the south-west Baltic area (2500-1500 BC): Why did the Bruszczewo-Łęki Małe power structures appear? (DFG-MU 1259/30-1/NCN-DEC2014/'l s/G/HS3/04720) for the financial and infrastructural support. We would further like to thank the research team ASOME (Arqueoecologia Social Mediterrània) from the Autonomous University of Barcelona and especially Roberto Risch, for his kind availability and the helpful comments provided during the preparation of this paper.

\section{References}

Adams, J., Delgado-Raack, S., Dubreuil, L., Hamon, C., Plisson, H. \& Risch, R. 2009, Functional analysis of macro-lithic artefacts. In: Non-Flint Raw Material Use in Prehistory. Old prejudices and new directions, Proceedings of the XV Congres UISSP, 4-9 September 2006 Lisboa (Sternke, F., Eigeland, L. \& Costa, L.-J., Eds.), British Archaeological Reports, International Series Vol. 1939, Archaeopress, Oxford: p. 43-66.

Bork, H.-R. 2010, Archäologische und umweltgeschichtliche Untersuchung eines markanten Sporns am westlichen Talrand der Samica. In: Bruszczewo II. Ausgrabungen und Forschungen in einer prähistorischen Siedlungskammer Großpolens (Müller, J., Czebreszuk, J. \& Kneisel, J., Eds.), Studien zur Archäologie in Ost-Mitteleuropa Vol. 6.1, Rudolph Habelt GmbH, Poznań-Bonn: p. 38-49. (in German) (“Archaeological and environmental analysis of a distinctive spur in the western valley border of the Samica”)

Budziszewski, J. 2015, Lithic arrowheads from the Bruszczewo settlement. In: Bruszczewo IV. Natural resources and economic activities of the Bronze Age people (Czebreszuk, J., Müller, J., Jaeger, M. \& Kneisel, J., Eds.), Studien zur Archäologie in Ost-Mitteleuropa Vol. 14, Rudolph Habelt GmbH, Poznań-Bonn: p. 243-248. 
Cailleux, A. 1951, Morphoskopische Analyse der Geschiebe und Sandkörner und ihre Bedeutung für die Paleoklimatologie. Geologische Rundschau, 40: 5-13. (in German) ("Morfoscopic analysis of moraines and sands and their significance for the palaeoclimatology") doi:10.1007/BF01803203

Czebreszuk, J., Müller, J. \& Silska, P. 2004, Forschungsgeschichte und Grabungsverlauf. In: Bruszczewo I. Ausgrabungen und Forschungen in einer prähistorischen Siedlungskammer Großpolens (Czebreszuk, J. \& Müller, J., Eds.), Studien zur Archäologie in Ostmitteleuropa Vol. 2, Uniwersytet im Adama Mickiewicza w Poznaniu, Christian-Albrechts-Universität Kiel, Poznań-Kiel-Rahden/Westf: p. 13-35. (in German) ("History of research and excavation process")

Czebreszuk, J. \& Müller, J., (Eds.) 2004, Bruszczewo I. Ausgrabungen und Forschungen in einer prähistorischen Siedlungskammer Großpolens. Studien zur Archäologie in Ostmitteleuropa Vol. 2, Uniwersytet im Adama Mickiewicza w Poznaniu, ChristianAlbrechts-Universität Kiel, Poznań-Kiel-Rahden/Westf, 333 p. (in German) ("Bruszczewo I. Excavations and research of a prehistoric settlement area of Great Poland")

Czebreszuk, J. \& Müller, J., (Eds.) 2015, Bruszczewo III. The settlement and fortification in the mineral zone of the site, Studien zur Archäologie in Ostmitteleuropa Vol. 13. Rudolph Habelt GmbH, Poznań-Bonn, 419 p.

Czebreszuk, J., Müller, J., Jaeger, M. \& Kneisel, J., (Eds.) 2015, Bruszczewo IV. Natural resources and economic activities of the Bronze Age people, Studien zur Archäologie in Ostmitteleuropa Vol. 14. Rudolph Habelt GmbH, Poznań-Bonn, 299 p.

Delgado-Raack, S. 2008, Prácticas Económicas y Gestión Social de Recursos (Macro)líticos en la Prehistoria Reciente (III-I milenios AC) del Mediterráneo Occidental. Ph. D. thesis no. 10803/5528 at the Department of Prehistory, Universitat Autònoma de Barcelona, Bellaterra, 739 p. (in Spanish) ("Economic Practices and Social Management of (Macro)lithic Resources During Recent Prehistory (III-I millennia BC) in the Western Mediterranean"). URL: http://hdl.handle.net/10803/5528

Delgado-Raack, S. 2011, La utilización de cantos y plaquetas en la secuencia estratigráfica de Santimamiñe. In: La Cueva de Santimamiñe. Revisión y actualización (2004-2006) (López Quintana, J. C., Ed.), Kobie BAI Vol. 1, Diputación Foral de Bizkaia, Bilbao: p. 171-196. (in Spanish) ("Santimamiñe Cave. Review and upgrade (2004-2006)") URL: http://www.bizkaia.eus/fitxategiak/04/ondarea/Kobie/PDF/7/Kobie_BAI_01_web.pdf?h ash=51d7a43126e582dbfc1ca13bb85ecaef

Delgado-Raack, S. 2018, The macrolithic artefacts of the wet soil area of Bruszczewo (Poland). Unpublished report prepared for the Department of Prehistory of the Christian-Albrechts University of Kiel, projects DFG-GSC208, DFG-SFB 1266, DFGMU 1259/30-1/NCN-DEC-2014/'l s/G/HS3/04720, on file. Barcelona, 70 p.; Date: 20.06.2018.

Hildebrandt-Radke, I. 2010, Das geologische Alter und die Hauptphasen der Denudationsund Akkumulationsprozesse vor dem Hintergrund topografischer Verhältnisse des archäologischen Fundplatzes Bruszczewo. In: Bruszczewo II. Ausgrabungen und Forschungen in einer prähistorischen Siedlungskammer Großpolens (Müller, J., Czebreszuk, J. \& Kneisel, J., Eds.), Studien zur Archäologie in Ost-Mitteleuropa Vol. 6.1, Rudolph Habelt GmbH, Poznań-Bonn: p. 16-37. (in German) ("Geological age and main phases of the erosive denudation and accumulation process") 
Hildebrandt-Radke, I. 2015, Geographical environment of the central Obra region and the geoarchaeology of an Early Bronze Age settlement at Bruszczewo. In: Bruszczewo IV. Natural resources and economic activities of the Bronze Age people (Czebreszuk, J., Müller, J., Jaeger, M. \& Kneisel, J., Eds.), Studien zur Archäologie in Ost-Mitteleuropa Vol. 14, Rudolph Habelt GmbH, Poznań-Bonn: p. 11-37.

Honig, P. 2004, Die Steine aus dem östlichen Feuchtbodenareal. In: Bruszczewo I. Ausgrabungen und Forschungen in einer prähistorischen Siedlungskammer Großpolens (Czebreszuk, J. \& Müller, J., Eds.), Studien zur Archäologie in Ostmitteleuropa, Vol. 2, Uniwersytet im Adama Mickiewicza w Poznaniu, Christian-Albrechts-Universität Kiel, Poznań-Kiel-Rahden/Westf: p. 247-256. (in German) ("Stones from the eastern wetland area")

Iwanek, B., Piontek, J. \& Nowak, O. 2010, Anthropologische Analyse des Skelettes aus Bruszczewo. In: Bruszczewo II. Ausgrabungen und Forschungen in einer prähistorischen Siedlungskammer Großpolens (Müller, J., Czebreszuk, J. \& Kneisel, J., Eds.), Studien zur Archäologie in Ostmitteleuropa Vol. 6.2, Rudolph Habelt GmbH, Bonn: p. 731-753. (in German) ("Anthropological analysis of the skeleton from Bruszczewo")

Jaeger, J., Czebreszuk, J., Müller, J. \& Kneisel, J. 2015, Metal finds. In: Bruszczewo IV. Natural resources and economic activities of the Bronze Age people (Czebreszuk, J., Müller, J., Jaeger, M. \& Kneisel, J., Eds.), Studien zur Archäologie in Ost-Mitteleuropa Vol. 14, Rudolph Habelt GmbH, Poznań-Bonn: p. 227-234.

Jaeger, J., Czebreszuk, J., Kneisel, J. \& Müller, J. 2016, Human remains from the Early Bronze Age fortified settlement in Bruszczewo. Preliminary report. In: Settlements of Life and Death. Studies from Prehistory to Middle Ages, Proceedings of an International Colloquium Tulcea, 25th-28th of May 2016 (Gogâltan, F. \& Ailincăi, S.C., Eds.), MEGA, Cluj-Napoca: p. 51-70.

Kneisel, J. 2010a, Aktivitätszonen und Ressourcennutzung in der Bronzezeit Großpolens. In: Siedlung und Handwerk. Studien zu sozialen Kontexten der Bronzezeit. Beiträge zu den Sitzungen der Arbeitsgemeinschaft Bronzezeit 2007 Schleswig und 2008 Mannheim (Horejs, B. \& Kienlin, T., Eds.), Universitätsforschungen zur prähistorischen Archäologie Vol. 194, Rudolph Habelt GmbH, Bonn: p. 1-18. (in German) ("Activity areas and use of resources in the Bronze Age of Great Poland")

Kneisel, J. 2010b, Eine Siedlungsbestattung der Frühbronzezeit. In: Bruszczewo II. Ausgrabungen und Forschungen in einer prähistorischen Siedlungskammer Großpolens (Müller, J., Czebreszuk, J. \& Kneisel, J., Eds.), Studien zur Archäologie in Ostmitteleuropa Vol. 6.2, Rudolph Habelt GmbH, Bonn: p. 724-729. (in German) ("A grave in a settlement from the Early Bronze Age")

Kneisel, J. 2013, Raumordnungen in der frühen und späten Bronzezeit am Beispiel Bruszczewos (Großpolen) und Umgebung. In: Parallele Raumkonzepte. Tagung des DAI 15.-17. März 2010 in Berlin. Topoi (Hansen, S. \& Meyer, M., Eds.), Studies of the Ancient World Vol. 16, De Gruyter, Berlin: p. 173-198. (in German) ("Spatial planning in the Early and Late Bronze Age in the example of Bruszczewo (Great Poland) and its surroundings") 
Kneisel, J. \& Kroll, H. 2010, Die Holzanalysen aus dem östlichen Feuchtbodenareal. In: Bruszczewo II. Ausgrabungen und Forschungen in einer prähistorischen Siedlungskammer Großpolens (Müller, J., Czebreszuk, J. \& Kneisel, J., Eds.), Studien zur Archäologie in Ost-Mitteleuropa Vol. 6.2, Rudolph Habelt GmbH, Poznań-Bonn: p. 576-661. (in German) ("Analysis of wood from the eastern wetland area")

Kneisel, J. \& Müller, J. 2011, Produktion, Distribution, Konsumption und die Formation sozialer Unterschiede in frühbronzezeitlichen Gesellschaften Mitteleuropas. In: Sozialarchäologische Perspektiven: Gesellschaftlicher Wandel 5000-1500 v. Chr. zwischen Atlantik und Kaukasus. Tagung 15.-18. Oktober 2007 Kiel (Hansen, S. \& Müller, J., Eds.), Archäologie in Eurasien Vol. 24, Philipp von Zabern, Mainz: p. 295324. (in German) ("Production, consumption and the formation of social differences in Early Bronze Age societies of Central Europe")

Kneisel, J., Czebreszuk, J., Dörfler, W., Grootes, P., Haas, J. N., Heussner, K.-U., Karg, S., Kroll, H., Müller, J., Wahlmüller, N. \& Wazny, T., 2008, Die Befestigte frühbronzezeitliche Siedlung Bruszczewo: Metallproduktion, feuchtbodenbefunde und ökologischer Kollaps?, Nachrichtenblatt Arbeitskreis Unterwasserarchäologie, 14: 5158. (in German) ("The fortified Early Bronze Age settlement of Bruszczewo: metal production, wetland findings and ecological collapse?")

Kneisel, J., Müller, J., Czebreszuk, J. \& Szmyt, M., 2012, Momentaufnahmen einer bronzezeitlichen Siedlung. Institut für Ur- und Frügeschichte der CAU Kiel, Kiel, 94 p. (in German) ("Snapshots of a Bronze Age settlement")

Kryszowski, A. 2015, Flint artefacts. In: Bruszczewo IV. Natural resources and economic activities of the Bronze Age people (Czebreszuk, J., Müller, J., Jaeger, M. \& Kneisel, J., Eds.), Studien zur Archäologie in Ost-Mitteleuropa, Vol. 14, Rudolph Habelt GmbH, Poznań-Bonn: p. 249-282.

Müller, J. \& Czebreszuk, J. 2010, Bruszczewo und Łęki Małe - Ein frühbronzezeitliches Machtzentrum in Großpolen. In: Der Griff nach den Sternen. Wie Europas Eliten zu Macht und Reichtum kamen; International Symposium February 16-21 2005, Halle (Saale) (Meller, H. \& Bertemes, F., Eds.), Tagungen des Landesmuseums für Vorgeschichte Vol. 5, Landesmuseums für Vorgeschichte, Halle/Saale: p. 381-396. (in German) ("An Early Bronze Age centre of power in Great Poland")

Müller, J., Czebreszuk, J. \& Kneisel, J. (Eds.) 2010, Bruszczewo II. Ausgrabungen und Forschungen in einer prähistorischen Siedlungskammer Großpolens, Studien zur Archäologie in Ostmitteleuropa Vol. 6.1-6.2. Rudolph Habelt GmbH, Bonn, 331 p. (in German) ("Burszczewo II. Excavations and research of a prehistoric settlement area of Great Poland")

Müller, J., Delgado-Raack, S., Escanilla, N., Kienle, L., Kneisel, J., Czebreszuk, J. \& Schürmann, U. 2020, First Evidence for the casting of gold-objects in an Early Bronze Age site of Central Europe. Unpublished article being prepared for publication, on file. Barcelona, 10 p.; Date: January 2020.

Pieczyński, Z. 1985, Umocnienia ochrońne osady z wczesnej epoki brązu w Bruszczewie, woj. Leszczyńskie, stan. 5. In: Frühbronzezeitliche befestigte Siedlungen in Mitteleuropa; Materialien der Internationalen Arbeitstagung, September 20-22 1983, Kraków (Kozłowski, J. \& Kozłowski, S. K., Eds.), Warsaw University, Warsaw: p.167182.(in Polish) ("Protective settlement structures of the Early Bronze Age in Bruszczewo") 
Risch, R. 2002, Recursos Naturales, Medios de Producción y Explotación Social. Un Análisis Económico de la Industria Lítica de Fuente Álamo (Almería), 2250-1400 Antes de Nuestra Era, Iberia Archaeologica Vol. 3. Philipp von Zabern, Mainz am Rhein, 340 p. (in Spanish) ("Natural Resources, Production Means and Social Exploitation. An Economic Analysis of the Stone Industry of Fuente Álamo (Almería), 2250-1400 BCE")

Risch, R., 2008, From production traces to social organisation: towards an epistemology of Functional Analysis. In: “Prehistoric Technology” 40 years later: Functional Studies and the Russian Legacy; Proceedings of the International Congress April 20-23 2005, Verona (Longo, L. \& Skakun, N., Eds.), British Archaeological Reports, International Series Vol. 1783, Archaeopress, Oxford: p. 513-521

Rudolph, F. 2008, Strandsteine. Sammeln und Bestimmen. Wachholtz, Neumünster, 160 p. (in German) ("Beach stones. Collecting and classifiying")

Rudolph F. 2010, Strandsteine. Sammeln und Bestimmen an Nord- und Ostsee. Wachholtz, Neumünster, 224 p. (in German) ("Beach stones. Collecting and classifying in the North and Baltic Seas")

Schwenzer, S. 2004, Przysieka Polska. Ein Grabfund in der Umgebung der frühbronzzezeitlichen Siedlung von Bruszczewo. In: Bruszczewo I. Ausgrabungen und Forschungen in einer prähistorischen Siedlungskammer Großpolens (Czebreszuk, J. \& Müller, J., Eds.), Studien zur Archäologie in Ostmitteleuropa Vol. 2, Uniwersytet im Adama Mickiewicza w Poznaniu, Christian-Albrechts-Universität Kiel, Poznań-KielRahden/Westf: p. 317-329. (in German) ("A grave finding in the sorroundings of the Early Bronze Age settlement of Bruszczewo")

Szmyt, M. 2015, Remains of the Neolithic settlements in Bruszczewo. Preliminary results. In: Bruszczewo III. The settlement and fortification in the mineral zone of the site (Czebreszuk, J. \& Müller, J., Eds.), Studien zur Archäologie in Ostmitteleuropa Vol. 13, Rudolph Habelt GmbH, Poznań-Bonn: p 43-51.

Szydłowski, M. 2015, Lithics from site 5 at Bruszczewo. In: Bruszczewo IV. Natural resources and economic activities of the Bronze Age people (Czebreszuk, J., Müller, J., Jaeger, M. \& Kneisel, J., Eds.), Studien zur Archäologie in Ost-Mitteleuropa Vol. 14, Rudolph Habelt GmbH, Poznań-Bonn: p. 235-242. 